\title{
Complex Sensory Corpuscles in the Upper Jaw of Horsfield's Tortoise (Testudo horsfieldii)
}

\author{
Marcela Buchtová ${ }^{1,2}$, Libor Páč ${ }^{3}$, Zdeněk Knotek ${ }^{4,5}$, František Tichý1 \\ ${ }^{1}$ Department of Anatomy and Histology, Faculty of Veterinary Medicine, University of Veterinary and \\ Pharmaceutical Sciences Brno, Czech Republic \\ ${ }^{2}$ Institute of Animal Physiology and Genetics, v.v.i., Academy of Sciences of the Czech Republic, Brno, \\ Czech Republic \\ ${ }^{3}$ Department of Anatomy, Masaryk University, Brno, Czech Republic \\ ${ }^{4}$ Avian and Exotic Animal Clinic, Faculty of Veterinary Medicine, University of Veterinary and Pharmaceutical \\ Sciences Brno, Czech Republic \\ ${ }^{5}$ Klinik für Geflügel, Ziervögel, Reptilien und Fische, Veterinärmedizinische Universität Wien, Austria
}

Received December 10, 2007

Accepted April 6, 2009

\begin{abstract}
The sensory corpuscles of Testudo horsfieldii in the skin of the upper lip and face were studied with light and electron microscopy. The sensory corpuscles were situated under epidermis; in the corium and also between the upper jaw bone tissues in the rostral part of oral cavity. The skin sensory corpuscles with a ramified inner core were grouped in clusters. Within the corpuscle there were several simple inner cores embedded within a common superficial capsule. The complex corpuscles have a novel structure in comparison to what has been described for sensory nerve endings in turtle. The complex sensory corpuscles probably function as mechanoreceptors important for monitoring the movement of the keratinized ridges and the most rostral part of the upper jaw, the rhamphotheci.
\end{abstract}

Mechanoreceptors, reptiles, Testudines, electron microscopy, lamellated encapsulated receptors

The upper jaw region has rich innervations containing many different receptors. For this reason, it is an important source of information. The innervation of the rostral part in head includes skin sensory receptors and sensory receptors of the oral cavity. In contrast to mammals, less attention has been paid to the structure of sensory corpuscles in the reptilian jaws. This study contributes to the understanding of innervations in the tortoise face and describes a novel type of encapsulated sensory corpuscles.

The reptilian sensory corpuscles were first described in the skin and oral cavity by several authors in the $19^{\text {th }}$ century (Leydig 1872; Cartier 1872; Leidy 1878; Merkel 1880) and later the studies have continued up to now (Hulanicka 1913; Aota 1940; Hin-Ching and Maneely 1962; Dingler 1964; Miller and Kasahara 1967; Siminoff and Kruger 1968; Proske 1969; Landman 1975; Soares 2002). However, they are mainly focused on crocodilian or snake sensory corpuscle structure.

The caiman face is covered with many small pigmented domes of integumentary sensory organs filled with lamellated receptors (von Düring 1973). These receptors are now named on the basis of functional observations as the dome pressure receptors (Soares 2002), and they can detect disruptions in the surface of surrounding water.

A detailed study of receptors in the upper jaw of Boa constrictor showed six different types of tissue receptors in their scales (von Düring 1974). Three types are located intraepithelially (radiant heat receptor, bubble receptor, receptor axons) and three types are laid in the corium (lamellated free receptors, branched lanceolate terminals, touch papillae). Physiological examination in the same species Boa contrictor (Hensel 1975) revealed the presence of warm receptors in their labial region, while no cold-sensitive fibres were

MVDr. Marcela Buchtová PhD.

Department of Anatomy and Histology

Faculty of Veterinary Medicine

University of Veterinary and Pharmaceutical Sciences Brno

Palackého 1/3, 61242 Brno, Czech Republic 
found. Nishida et al. (2000) discovered sensory papillae located along the teeth rows of the snake (Elaphe quadrivirgata). Each sensory papilla is comprised of a taste bud, free nerve endings in the epithelium, Meissner-like corpuscles, branched coiled terminals and lamellated corpuscles in the connective tissue.

Dingler (1964) found simple sensory corpuscles in Egernia cunnighami (Scincidae). Miller and Kasahara (1967) reported on the innervations of lizard skin and Proske (1969) on those of the snake Pseudechis porphyriacus. Landmann and Halata (1980) examined the labial epidermis of the lizard (Podarcis siculus) and found Merkel cells and nerve endings there. Burnasheva (1965) described corpuscles in the ducts of the Harderian gland in lizards and tortoises.

Less attention has been given to the turtle sensory system. Hin-Ching and Maneely (1962) described branched coiled terminals of the dermis in the soft-shelled turtle Pelodiscus sinensis (syn. Trionyx sinensis). A different type of encapsulated corpuscles were formed in the joint capsules of the tortoise Testudo graeca and Emys orbicularis: spray-like ramified encapsulated corpuscles with an inner core (Páč 1968, 1975). Von Düring and Miller (1979) mentioned the presence of encapsulated lamellated receptors in Testudo graeca without detailed documentation and description. In contrast to other reptilian groups, the upper jaw of cheloniids is covered by keratinous beak - the rhamphotheca (Wyneken 2003). Tortoises are edentulous, therefore the sharp edges of the rhamphotheca take the functional place of teeth. Considering the different external morphology and function of the upper jaw, we have posed the question whether the innervation of the tortoise lip is adapted to the changed functional requirements.

\section{Materials and Methods}

The sensory corpuscles with the inner core were studied with light and transmission electron microscopy (TEM). Five upper jaws were collected from adult tortoise - Testudo horsfieldii Gray, 1844. Each of these patients was euthanized due to the clinical status related to chronic liver disease and/or chronic renal failure. The intramuscular injection of ketamine/xylazine was followed with T61 into the dorsal tail vein (vena coccygea dorsalis).

Two heads were fixed in 10\% formaldehyde for light microscopy. After dehydration the material was embedded in paraffin, serial histological sections were prepared $(5 \mu \mathrm{m})$ and stained with either Gömöri stain, haematoxylineosin or Alcian blue.

Three upper jaws for electron microscopy were fixed in $4 \%$ glutaraldehyde following $2 \%$ solution of $\mathrm{OsO}_{4}$. After dehydration the material was embedded in Durcupan (ACM Fluka). Semithin and ultrathin sections were made on Tesla BS ultramicrotome. The ultrathin sections were treated with the water solution of uranylacetate and lead citrate to increase contrast. They were examined and photographed on Tesla BS 500 electron microscope.

\section{Results}

Sensory corpuscles are situated under epidermis in the upper jaw. The tortoise jaws do not contain teeth but around the margins there are sharp ledges formed by a thick layer of keratinized epidermis (Plate I, Fig. 1, Plate II, Fig. 2a). Under the epidermis there is a thin zone of dermis composed of several layers of dense collagenous connective tissue distinctly alternating in direction. Many chromatocytes are situated near epidermis (Plate II, Fig. 2a, Fig. 2b). Dermal papillae are absent. The sensory corpuscles are not only in the corium but also between the upper jaw bone tissues in the rostral part of the oral cavity (Fig. 2b). The corpuscle diameter varies from 60 to $150 \mu \mathrm{m}$.

The ultrastructural studies showed a novel arrangement that has not been described previously for turtle sensory organs. The corpuscles in the upper jaw have a ramified inner core and they are grouped together in clusters of several axons. Their inner structure is more complicated than the structure of simple sensory corpuscles. There are some simple inner cores located inside the corpuscle. The complex structure - all simple inner cores is embedded inside the common superficial capsule.

Each simple inner core is formed by a centrally located axon (its dendritic zone) and by few cells of inner core arranged around it (Plate II, Fig. 2c,d). The myelinated axon 
enters into the corpuscle (Plate II, Fig. 2e). After passing through the capsule, the myelin sheath comes to an end (near the inner core border). Cells of the inner core are modified Schwann cells (Plate II, Fig. 2c,d,f). The individual inner cores are not separated by the parts of capsular lamellar cells. There are structures of boundary space (Fig. 2c,e) filled with collagenous microfibrills and individual fibrocytes situated among the individual (neighbouring) inner cores. The whole corpuscle is bounded with a simple lamellous capsule (Plate II, Fig. 2g,h). The capsule is formed by flat lamellar cells from two to four layers. These capsular cells are of epineural type.

\section{Disscusion}

The sensory nerve endings of Testudo horsfieldii belong to the IIIb class using the classification of Malinovský and Páč (1982). These nerve endings are called the sensory corpuscles and their terminals are in the relation to Schwann cells. These cells form the lamellar inner core.

Until now, only one publication reported turtle sensory corpuscles in the orofacial region. Hin-Ching and Maneely (1962) described nerve endings in Pelodiscus sinensis. In the snout area they demonstrated very different types of nerve endings (only simple receptors) from our finding in Testudo horsfieldii. v o n Düring and Miller (1979) in their review of reptilian sensory nerve endings mentioned the presence of encapsulated lamellated receptors in Testudo graeca as unpublished observations. Unfortunately, they did not provide any photographical documentation or close description of their observations, and the location of the receptors was not characterized. Thus, it is difficult to compare our findings but we assume the presence of similar corpuscles also in other chelonians.

The upper and lower jaws of cheloniids are covered by the rhamphotheca (Wyneken 2003) and the shape of these keratinous beaks varies with diet (Schumacher 1973; Ruckdeschel et al. 2000). Tortoise sensory corpuscles lay near the base of these keratinous beaks. We suggest that the corpuscles function to monitor beak movement similarly to Herbst corpuscles and Ruffini corpuscles in birds. Although the tortoise sensory corpuscles are located in the same part of orofacial region as the corpuscles in birds, there are two major differences in the ultrastructure. The tortoise corpuscles are grouped in clusters with a ramified inner core, which we can never see in Herbst corpuscles (Malinovský and Páč 1980). The Ruffini corpuscles are also arranged in groups of up to ten corpuscles (Halata and Grim 1993) in the beak of Japanese quail (Coturnix japonica), similarly to tortoise corpuscles, but each corpuscle is surrounded by an incomplete fibrous capsule.

Comparing the tortoise corpuscles to other reptilian species, Nishida et al. (2000) discovered lamellated corpuscles in the snake oral cavity that lacked a capsule. Similar arrangement to our tortoise corpuscles was described in the caiman (von Düring 1973; von Düring and Miller 1979). These sensory corpuscles also have a looser lamellation with capsule space. In comparison to Caiman, Natrix and Varanus (von Düring 1973) where the lamellated receptors are associated with papillae, our tortoise corpuscles do not seem associated with a specific surface structure of the face. Caiman receptors are more similar to our findings but only rarely two receptor axons may run parallel inside one single capsule space. In tortoise receptors, two to five axons can run together within a common capsule. While caiman sensory corpuscles are components of the touch papillae and this area is covered by a thin skin layer (von Düring 1973), tortoise sensory corpuscles occur in a deeper dermis layer between bones and have no contact with the surface. Therefore the tortoise corpuscles may function quite differently from the caiman corpuscles.

Does the similarity of tortoise and bird corpuscles reflect a functional adaptation for beak movement monitoring? Or do they reflect a conserved developmental programme of facial structures in turtles and birds compared to scaled reptiles? This question requires further examination of turtle species with a different arrangement of facial structures, e.g. the 
leatherback sea turtle Dermochelys coriacea that lacks a distinct rhamphotheca on either jaw (Wyneken 2003).

Some of the recent reports discussed the phylogenetic position of the turtles (Hill 2005). Molecular findings of mitochondrial genomes indicated that turtles are not a basal lineage among the anapsid reptiles (Zardoya and Meyer 1998; Cao et al. 2000; Janke et al. 2001), and the anapsids seem to be paraphyletic themselves (Rieppel 1999). Mindell et al. (1999) found a sister relationship between turtles and a bird/crocodilian clade. Caspers et al. (1996) indicated that turtles branched off from the amniote tree after the mammals. Turtles have a partially developed secondary palate and a more complicated structure of sensory corpuscles in the upper jaw compared to scaled reptiles. Molecular data support the new morphological findings that turtles are more derived than early studies proposed (Carroll 1988). Our finding of complex sensory corpuscles in the Testudo horsfieldii suggests the necessity of further study of sensory corpuscles in other reptiles in order to determine where the complex sensory corpuscles originate phylogenetically. Malinovský and Páč (1982) suggested that amphibians and reptiles only have simple corpuscles, yet our recent findings of sensory corpuscles with a ramified inner core in tortoise showed that in reptiles also complex corpuscles are present. Since simple lamellated receptors were described in amphibians (Bolgarskij 1964; von Düring and Seiler 1974), complex sensory corpuscles probably appeared first in reptiles.

\section{Složitá smyslová tělíska v horní čelisti Testudo horsfieldii}

Smyslová tělíska, která se nacházejí v kůži horní čelisti u želvy, Testudo horsfieldii, byla studována pomocí světelného a transmisního elektronového mikroskopu. Tělíska jsou umístěna pod epidermis, ve škáře a rovněž mezi kostními lamelami horní čelisti v rostrální části ústní dutiny. Tato komplexní nervová zakončení mají odlišnou strukturu ve strovnání s dosud popsanými tělísky u želv. Tělíska vytváŕí shluky, z nichž každé obsahuje několik zón označovaných jako vnitřní jádra, která jsou obaleny společnou povrchovou pochvou. Jednotlivá vnitřní jádra mají centrálně umístěný axon a modifikované Schwannovy buňky ho obklopují. Tato složitá smyslová tělíska pravděpodobně působí jako mechanoreceptory, které jsou nezbytné pro monitorování pohybu zrohovělých okrajů čelistí, přičemž jeho ostré okraje slouží jako funkční náhrada dentice u želv.

\section{Acknowledgements}

We thank M. Mišková and J. Menšíková for their help with tissue processing and H.L. Szabo-Rogers for careful reading and providing critical comments on the manuscript. M. Buchtová is supported by the Grant Agency of the Czech Academy of Sciences (KJB601110919).

\section{References}

Aota S 1940: A histological study of the integument of a blind snake, Tuphlops braminus (Daudin) with special reference to the sense organs and nerve ends. J Sci Hiroshima Univ Ser B 7: 193-208

Bolgarskij JA 1964: Zur Frage über die besonderer Formen der rezeptorischen Nervenapparate der Haut der Amphibien. Anat Anz 114: 38-47

Burnasheva DV 1965: Nerve apparatuses of some accessory structures of eye in Sauropsida (in Russian). Arkh Anat Gistol Embriol 48: 74-79

Cao Y, Sorenson MD, Kumazawa Y, Mindell DP, Hasegawa M 2000: Phylogenetic position of turtles among amniotes: evidence from mitochondrial and nuclear genes. Gene 259: 139-148

Carroll RL 1988: Vertebrate Paleontology and Evolution. W. H. Freeman, New York.

Cartier O 1872: Studien über den feineren Bau der Haut bei den Reptilien. Verhandl Würz Phys-Med Gesell 1:83-96

Caspers GJ, Reinders GJ, Leunissen JA, Wattel J, De Jong WW 1996: Protein sequences indicate that turtles branched off from the amniote tree after mammals. J Mol Evol 42: 580-586

Dingler EC 1964: Nervendigungen in Reptilienzungen (In German). Verh Anat Ges 59: 372-373

Halata Z, Grim M 1993: Sensory nerve endings in the beak skin of Japanese quail. Anat Embryol 187: 131-138

Hensel H 1975: Static and dynamic activity of warm receptors in Boa constrictor. Pflugers Arch 353: 191-199 
Hill RV 2005: Integration of morphological data sets for phylogenetic analysis of amniota: the importance of integumentary characters and increased taxonomic sampling. Syst Biol 54: 530-547

Hin-Ching L, Maneely RB 1962: Some cutaneous nerve endings in the soft-shelled turtle of south China. J Comp Neurol 119: 381-389

Hulanicka R 1913: Note préliminaire sur les terminaisons nerveuses dans la peau et la muqueuse de la langue et du palais de crocodile. Anat Anz 43: 326-333

Janke A, Erpenbeck D, Nilsson M, Arnason U 2001: The mitochondrial genomes of the iguana (Iguana iguana) and the caiman (Caiman crocodylus): implications for amniote phylogeny. Proc Biol Sci 268: 623-631

Landmann L 1975: The sense organs in the skin of the head of Squamata (Reptilia). Isr J Zool 24: 99-135

Landmann L, Halata Z 1980: Merkel cells and nerve endings in the labial epidermis of a lizard. Cell Tiss Res 210: $353-357$

Leydig F 1872: Zur Kenntniss der Sinnesorgane der Schlangen. Arch Mikr Anat 8: 317-357

Leidy J 1878: Über einige Körper in der Boa constrictor, welche der Pacinischen Körperchen gleichen. Arch Anat Physiol 2: 527-330

Malinovský L, Páč L 1980: Ultrastructure of the Herbst corpuscle from the beak skin of the pigeon. Z Mikrosk Anat Forsch 94: 292-304

Malinovský L, Páč L 1982: Morphology of sensory corpuscles in mammals. Acta Fac Med Univ Brunensis 79: 5-219

Merkel F 1880: Über die Endigungen der sensiblen Nerven in der Haut der Wirbelthiere. Leizpig.

Miller M, Kasahara M 1967: Studies on the cutaneous innervation of lizards. Proc Calif Acad Sci 34: 549-568

Mindell D, Sorenson M, Dimcheff D, Hasegawa M, Ast J, Yuri T 1999: Interordinal relationships of birds and other reptiles based on whole mitochondrial genomes. Syst Biol 48: 138-152

Nishida Y, Yoshie S, Fujita T 2000: Oral sensory papillae, chemo- and mechano-receptors, in the snake, Elaphe quadrivirgata. A light and electron microscopic study. Arch Histol Cytol 63: 55-70

Páč L 1968: Sensory nerve endings in the joint capsules of the tortoise (Testudo graeca). Folia Morphol (Prague) 16: $43-47$

Páč L 1975: Ultrastructure of the joint receptors of the tortoise (Testudo graeca, Emys orbicularis). Z Mikrosk Anat Forsch 89: 1068-1078

Proske U 1969: Nerve endings in skin of the Australian black snake. Anat Rec 164: 259-266

Rieppel O 1999: Turtle origins. Science 283: 945-946

Ruckdeschel C, Shoop CR, Zug GR 2000: Sea Turtles of the Georgia Coast. Cumberland Island Museum, St. Marys GA.

Schumacher GH 1973: Head muscles and hyolaryngeal skeleton of turtles and crocodilians. In: Gans C, Parsons TS (Eds.): Biology of the Reptilia. Academia Press New York, pp. 101-199.

Siminoff R, Kruger L 1968: Properties of reptilian cutaneous mechanoreceptors. Exp Neurol 20: 403-414

Soares D 2002: An ancient sensory organ in crocodilians. Nature 417: 241-242

von Düring M 1973: The ultrastructure of lamellated mechanoreceptors in the skin of reptiles. Z Anat Entwickl Gesch 143: 81-94

von Düring M 1974: The radiant heat receptor and other tissue receptors in the scales of the upper jaw of Boa constrictor. Z Anat Entwickl Gesch 145: 299-319

von Düring M, Miller MR 1979: Sensory nerve endings of the skin and deeper structures. In: Gans C, Northcutt RG, Ulinski P (Eds.): Biology of the Reptilia. Vol. 9. pp. 407-411. Academic Press, New York, pp. 407-411.

von Düring M, Seiler W 1974: The fine structure of lamellated receptors in the skin of Rana esculenta. Z Anat Entwickl Gesch 144: 165-172

Wyneken J 2003: The external morphology, musculoskeletal system, and neuro-anatomy of sea turtles. In: Lutz PL, Musick JA, Wyneken J (Eds.): The Biology of Sea Turtles II. CRC Press, Boca Raton, pp. 39-77.

Zardoya R, Meyer A 1998: Complete mitochondrial genome suggests diapsid affinities of turtles. Proc Natl Acad Sci USA 95: 14226-14231 
Plate I

Buchtová M. et al.: Complex Sensory ... pp. 193-197

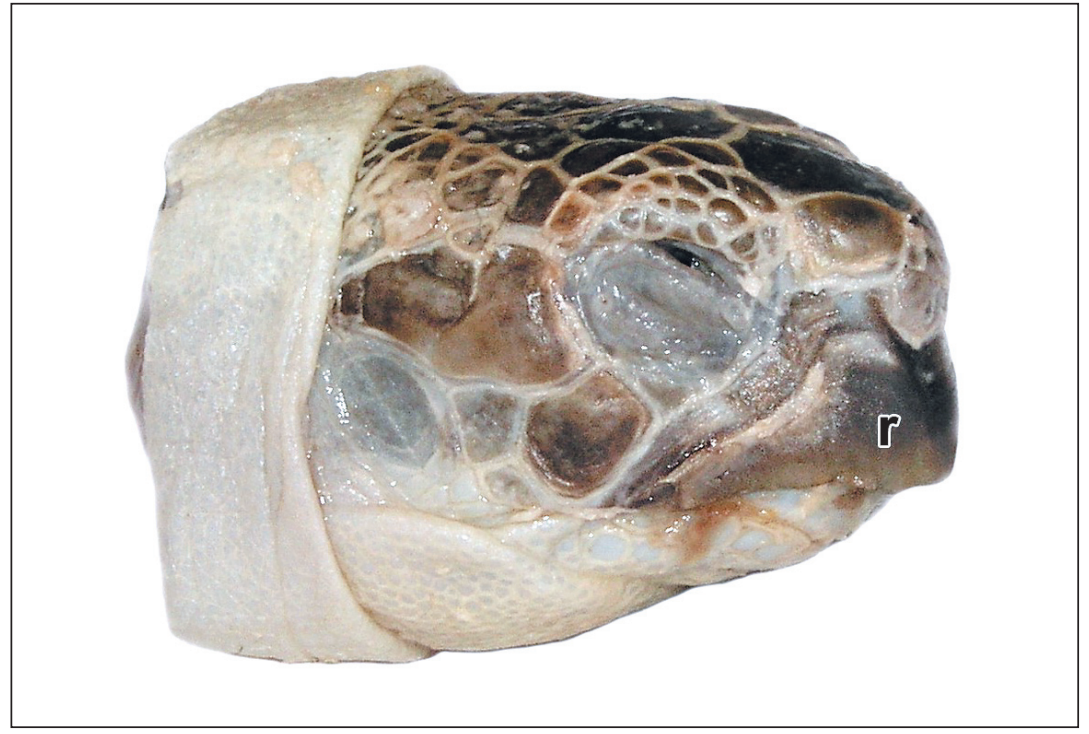

Fig. 1. The head of a Horsfield's tortoise, $r$ - rhamphotheca 

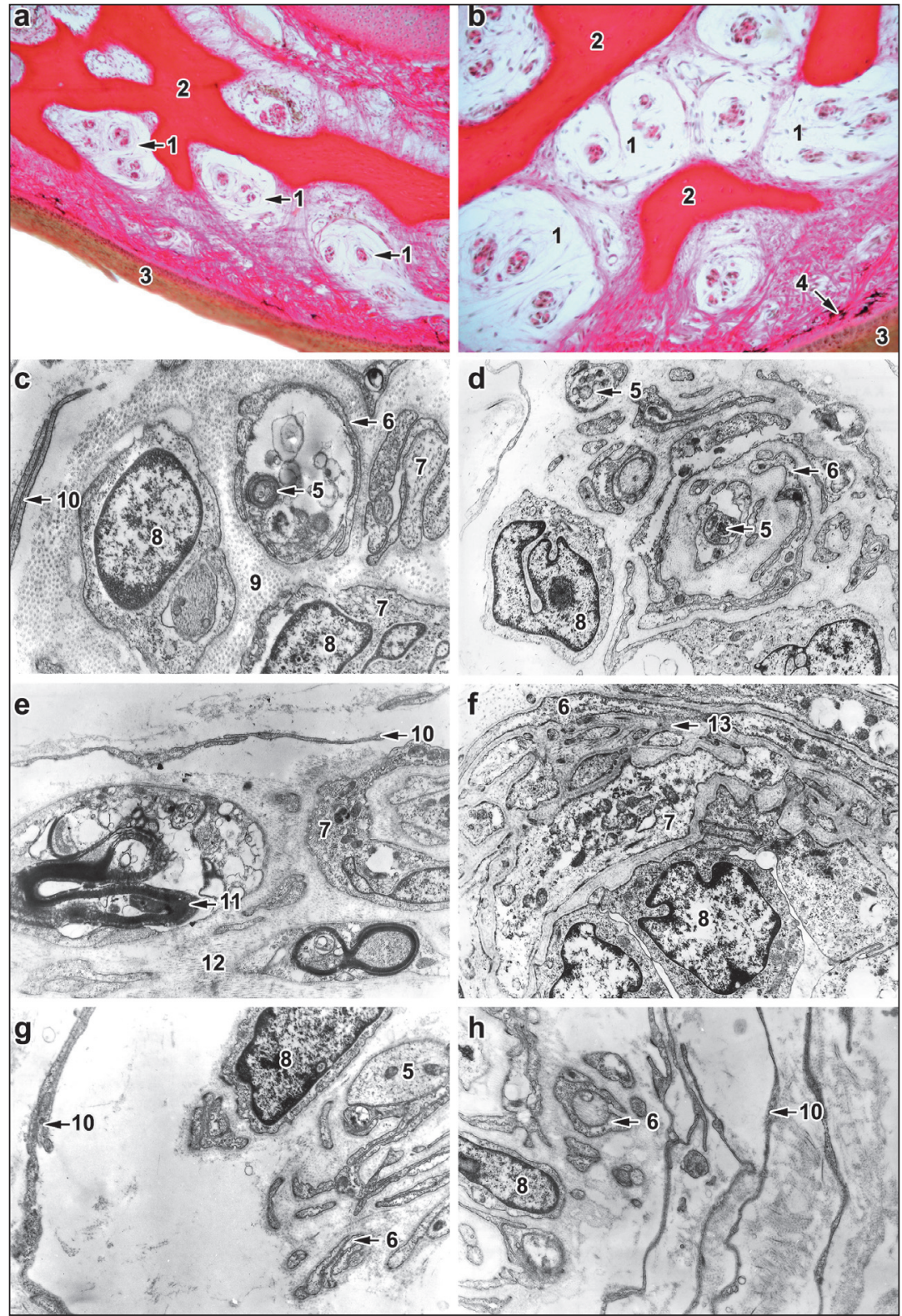

Fig. 2. Transversal section of the upper jaw. a, b: Hematoxylin-eosin, c-h: TEM.

1 - sensory corpuscles, 2 - bone tissue, 3 - epidermis, 4 - corium with chromatocytes, 5 - axon (sensory nerve terminal), 6 - inner core cell lamellae around nerve terminal, 7 - inner core cell, 8 - nucleus of inner core cell, 9 - boundary space filled with collagen microfibrils, 10 - capsular lamellae, 11 - axon with myelin sheath entering the inner core, 12 - boundary space, 13 - inner core space. Magnification: $\mathrm{a}-\times 100, \mathrm{~b}-\times 200, \mathrm{c}-\mathrm{h}-\times 12.000$ 